\title{
Tropospheric ozone behaviour as a function of precursor emissions
}

\author{
S. Carletti \& G. Passerini \\ Department of Industrial Engineering and Mathematical Sciences, \\ Marche Polytechnic University, Italy
}

\begin{abstract}
Several air-quality monitoring stations, located along the Marche Region coastline, recorded, over the last decade, high concentrations of tropospheric ozone. For this reason, analysing the formation of photochemical smog, particularly in an Area at High Risk of Environmental Crisis (AERCA) became a crucial task. To evaluate ozone dynamics as a function of precursor emissions and local meteorology, we implemented a modelling system made of RAMS (Regional Atmospheric Modelling System), EPS3 (Emission Processor Ver. 3), CAMx (Comprehensive Air quality Model with eXtensions), and OSAT (Ozone Source Apportionment Technology). CAMx is an Eulerian photochemical dispersion model that allows the assessment of gaseous and particulate air pollution over many scales ranging from sub-urban to continental. Thus CAMx is the kernel of the modelling chain while the OSAT tool allows CAMx to track source-region and source-category contributions to the predicted ozone concentrations. For any selected receptor and for any selected period, the model gives information about the likely distribution of ozone and ozone precursors by source category and by source region. Similarly, it assesses whether the ozone at the selected time and location would more likely respond to upwind $\mathrm{NO}_{\mathrm{X}}$ or VOC controls. By means of such models, it was possible to map the ozone behaviour in diverse areas and to assess the impacts of different types of source emission and sectors. Such results also allowed us to develop a possible choice ozone-control strategy to reduce ozone peaks and to avoid ozone episodes.

Keywords: tropospheric ozone, CAMx, OSAT, air control strategies.
\end{abstract}




\section{Introduction}

This work presents a rather complex set of simulations carried out to better describe the ozone behaviour in the Marche Region especially in a particular area located across the Adriatic Sea. The area was declared "Highly at Risk of Environmental Crisis" (AERCA) by Regional Authorities and competent Ministries. The risk is mainly due to the concurrent presence of a big oil refinery, several highways, the local airport, and a rather big port, including industrial harbours. This situation led to high levels of several different species of pollutants. Between all, in the past, Volatile Organic Compounds (VOCs) levels and Nitrogen Oxides $\left(\mathrm{NO}_{\mathrm{X}}\right)$ levels often reached and overcame legal limits. It is well known that VOCs and $\mathrm{NO}_{\mathrm{X}}$ concur to the formation of Photochemical Smog and their comparative and absolute concentrations deeply affect ground ozone dynamics and ozone cycles. In fact, during past years, comparatively high concentrations of ozone were registered by monitoring stations in the analysed area and in other districts of Marche Region.

The Ozone dynamics in AERCA and for the whole Marche Region was modelled in-deep by the means of the photochemical model CAMx (Comprehensive Air quality Model with eXtensions) with the additional implementation of a dedicated probing tool called OSAT (Ozone Source Apportionment Technology) specially developed for the appointment of precursor sources according to the ozone dynamics.

The results provided us with important information about the conditions of ozone formation, the role of each single emission group, and, more specifically, information about when and where a certain pollutant involved in the ozone dynamics was released.

\section{Human health effects and climate interactions}

Ozone is continually produced and destroyed in the atmosphere by chemical reactions. The respiratory system is the primary target of the ozone oxidizing effects on human health. Exposure to elevated concentrations is associated with increased hospital admissions for pneumonia, chronic obstructive pulmonary disease, asthma, allergic rhinitis and other respiratory diseases [1]. The extent of adverse respiratory consequences due to ground-level ozone depends on a number of factors, including pollutant concentrations, duration of exposure, local climate, individual sensitivity, and any pre-existent respiratory disease. The Air Quality Standards in Italy, according to Europe, define the maximum daily eighthour mean of $120 \mu \mathrm{g} / \mathrm{m}^{3}$ and the information threshold of $180 \mu \mathrm{g} / \mathrm{m}^{3}$ during one hour [2].

Tropospheric ozone is also a greenhouse gas: after carbon dioxide and methane, it is the third most important contributor to greenhouse radiative forcing [3]. Since pre-industrial era, the radiative forcing value due to tropospheric ozone is estimated to be $+0.35 \mathrm{~W} / \mathrm{m}^{-2}$ (range $0.25-0.65$ ). 


\section{Ozone formation in the troposphere}

\subsection{The role of $\mathrm{VOC}$ and of $\mathrm{NO}_{\mathrm{X}}$}

Tropospheric ozone is produced by photochemical oxidation of carbon monoxide (CO), methane $\left(\mathrm{CH}_{4}\right)$ and non-methane volatile organic compounds (VOC) in the presence of $\mathrm{NO}_{\mathrm{X}}$. The hydroxyl radical $(\mathrm{OH})$ is the key reactive species in the chemistry of ozone formation, and it can react with $\mathrm{CO}, \mathrm{CH}_{4}$ and VOC. In general, methane is not simulated explicitly in ozone models. The sensitivity of ozone formation to $\mathrm{VOC}$ and $\mathrm{NO}_{\mathrm{X}}$ at any given time is attributable to the fate of radicals, and the production does not increase linearly with an increase in the precursors concentrations. In general, increasing VOC concentrations means more ozone while increasing $\mathrm{NO}_{\mathrm{X}}$ may lead to either more or less ozone depending on the prevailing VOC-to- $\mathrm{NO}_{\mathrm{X}}$ ratio [4].

The radical pool is often referred to as odd hydrogen $\left(\mathrm{HO}_{\mathrm{X}}\right)$ and is most usefully considered as the sum of $\mathrm{OH}, \mathrm{HO}_{2}$ and $\mathrm{RO}_{2}$ radicals. Ozone formation occurs through the following sequence of reactions. The sequence is usually initiated by the reaction of various $\mathrm{CO}$ or $\mathrm{VOC}$ with the $\mathrm{OH}$ radical according to formulae (1) and (2).

$$
\begin{aligned}
& \mathrm{CO}+\mathrm{OH} \stackrel{+\mathrm{O}_{2}}{\longrightarrow} \mathrm{CO}_{2}+\mathrm{HO}_{2} \\
& \mathrm{RH}+\mathrm{OH} \stackrel{+\mathrm{O}_{2}}{\longrightarrow} \mathrm{RO}_{2}+\mathrm{H}_{2} \mathrm{O}
\end{aligned}
$$

This is followed by the conversion of $\mathrm{NO}$ to $\mathrm{NO}_{2}$ through reaction with $\mathrm{HO}_{2}$ or $\mathrm{RO}_{2}$ radicals, which also regenerates $\mathrm{OH}$ according to formulae (3) and (4). $\mathrm{RO}_{2}$ represents any of a number of chains of organics with an $\mathrm{O}_{2}$ attached

$$
\begin{gathered}
\mathrm{HO}_{2}+\mathrm{NO} \rightarrow \mathrm{NO}_{2}+\mathrm{OH} \\
\mathrm{RO}_{2}+\mathrm{NO} \stackrel{+\mathrm{O}_{2}}{\rightarrow} \mathrm{R}^{\prime} \mathrm{CHO}+\mathrm{HO}_{2}+\mathrm{NO}_{2}
\end{gathered}
$$

$\mathrm{NO}_{2}$ is photolyzed to generate atomic oxygen, which combines with $\mathrm{O}_{2}$ to create $\mathrm{O}_{3}$ through reaction (5) and (6).

$$
\begin{gathered}
\mathrm{NO}_{2}+h v \rightarrow \mathrm{NO}+\mathrm{O} \\
\mathrm{O}+\mathrm{O}_{2}+M \rightarrow \mathrm{O}_{3}+M
\end{gathered}
$$

Ozone episodes in polluted regions are usually due to the ozone production sequence shown above. However, at night-time and in the immediate vicinity of very large emissions of $\mathrm{NO}$, ozone concentrations are depressed through the process of $\mathrm{NO}_{\mathrm{X}}$ titration, according to the formula (7).

$$
\mathrm{O}_{3}+\mathrm{NO} \rightarrow \mathrm{NO}_{2}+\mathrm{O}_{2}
$$

There is a competition between $\mathrm{VOC}$ and $\mathrm{NO}_{\mathrm{X}}$ for the $\mathrm{OH}$ radical. At a high ratio of VOC to $\mathrm{NO}_{\mathrm{X}}$ concentration, $\mathrm{OH}$ will react mainly with $\mathrm{VOC}$ while, at a low ratio, the $\mathrm{NO}_{\mathrm{X}}$ reaction can predominate [4].

When the $\mathrm{VOC} / \mathrm{NO}_{\mathrm{X}}$ concentration ratio is approximately $5.5: 1$, with the VOC concentration expressed on a carbon atom basis, the rates of reaction of VOC and $\mathrm{NO}_{\mathrm{X}}$ with $\mathrm{OH}$ are equal. Whenever the $\mathrm{VOC} / \mathrm{NO}_{\mathrm{X}}$ ratio is lower than 5.5:1, reaction of $\mathrm{OH}$ with $\mathrm{NO}_{2}$ predominates over reaction of $\mathrm{OH}$ with VOC. 
The $\mathrm{OH}-\mathrm{NO}_{2}$ reaction (8) removes $\mathrm{OH}$ radicals from the active VOC oxidation cycle, retarding the further production of $\mathrm{O}_{3}$.

$$
\mathrm{OH}+\mathrm{NO}_{2}+\mathrm{M} \rightarrow \mathrm{HNO}_{3}+\mathrm{M}
$$

Under these conditions, called VOC-limited, a decrease in $\mathrm{NO}_{\mathrm{X}}$ emissions favours $\mathrm{O}_{3}$ formation. Conversely, when the ratio exceeds 5.5:1, OH reacts preferentially with VOC. At very low $\mathrm{NO}_{\mathrm{X}}$ concentration, reaction (9) becomes significant and it removes free radicals from the system.

$$
\mathrm{HO}_{2}+\mathrm{HO}_{2} \rightarrow \mathrm{H}_{2} \mathrm{O}_{2}+\mathrm{O}_{2}
$$

This condition is named $\mathrm{NO}_{\mathrm{X}}$-limited, because the growth of $\mathrm{NO}_{\mathrm{X}}$ emissions induces the reaction (3) and consequently the ozone formation.

\subsection{Sillman indicator}

In reality, many of the trajectories start out VOC-limited and become $\mathrm{NO}_{\mathrm{X}}{ }^{-}$ limited during the course of the day essentially because the $\mathrm{NO}_{\mathrm{X}}$ is depleted more rapidly than the $\mathrm{VOC}$.

Nitric acid $\left(\mathrm{HNO}_{3}\right)$ production, according to the reaction (8), is indicative of plentiful $\mathrm{NO}_{\mathrm{X}}$ while peroxide formation $\left(\mathrm{H}_{2} \mathrm{O}_{2}\right)$ is indicative of scarce $\mathrm{NO}_{\mathrm{X}}$.

Sillman [5] has exploited this situation to develop useful indicators of VOC vs. $\mathrm{NO}_{\mathrm{X}}$-limited ozone formation based on the ratio of peroxide production to nitric acid production. Sillman proposed that the transition between these conditions occurs when:

$$
P_{\mathrm{H}_{2} \mathrm{O}_{2}} / P_{\mathrm{HNO}_{3}}=0.35
$$

Before midday, with an initial $\mathrm{VOC} / \mathrm{NO}_{\mathrm{X}}$ ratio $10: 1$, the Sillman ratio is less than 0.35 indicating a VOC-limited ozone formation. After that, it exceeds 0.35 indicating a $\mathrm{NO}_{\mathrm{X}}$-limited ozone formation. After sunset, the ratio falls below 0.35 again, but this is after the ozone peak and the concepts of VOC-limited and $\mathrm{NO}_{\mathrm{X}}$-limited are no longer relevant [6].

The true impacts of VOC is related more closely to the reactivity of the VOC species with respect to $\mathrm{OH}$ rather than to the total amount of VOC. Locations with highly reactive VOC, e.g. xylene or isoprene, are more likely to have $\mathrm{NO}_{\mathrm{X}^{-}}$ limited chemistry than locations with similar total VOC but lower reactivity [7]. For this reason, the photochemical models require the chemical speciation of the emission inventory.

\section{Ozone modelling system}

\subsection{Meteorological model}

A coastal region is influenced by many meteorological phenomena due to the interactions between breezes and large-scale wind systems. Mesoscale air flows in coastal regions are mainly determined by land-sea temperature contrast that drives land-sea breezes, and by the orography that drives mountain-valley breezes while the shape of the coastline has an effect on mesoscale wind flow [8]. A mesoscale meteorological model (RAMS) has been used. RAMS is a 
versatile modelling system capable of simulating flows from the scale of a global hemisphere to the scale of a building [9] with numerous options including multiple nesting, and several convective and boundary layer parameterization options.

\subsection{Emission inventory and model input}

A photochemical model simulates the hour-by-hour photochemistry occurring for each grid cell in the modelling domain; consequently, the input emissions data must contain a comparable level of resolution. Total emissions (e.g., VOC, $\mathrm{NO}_{\mathrm{X}}$ ) must be chemically allocated into the chemical classes employed by the model. Additionally, the emissions data must be spatially allocated by grid cell for each hour of the modelling episode [10]. The flexibility of EPS3 (Emissions Processing System, version 3.20) provides the user with many options for processing their emissions inventory. EPS3 consists of a series of Fortran modules that perform these intensive data manipulations, producing an emissions inventory for photochemical modelling. Referring to ozone assessment, the model is usually applied for a multi-day period during which adverse meteorological conditions result in elevated concentrations. For the present study, we used three differed grids: one master grid and two nested grids. The coarse grid (G1), as shown in Figure 1(a), is 960x800km wide and covers most of continental Italy through its $60 \times 50$ cells with $16 \mathrm{~km}$ step.

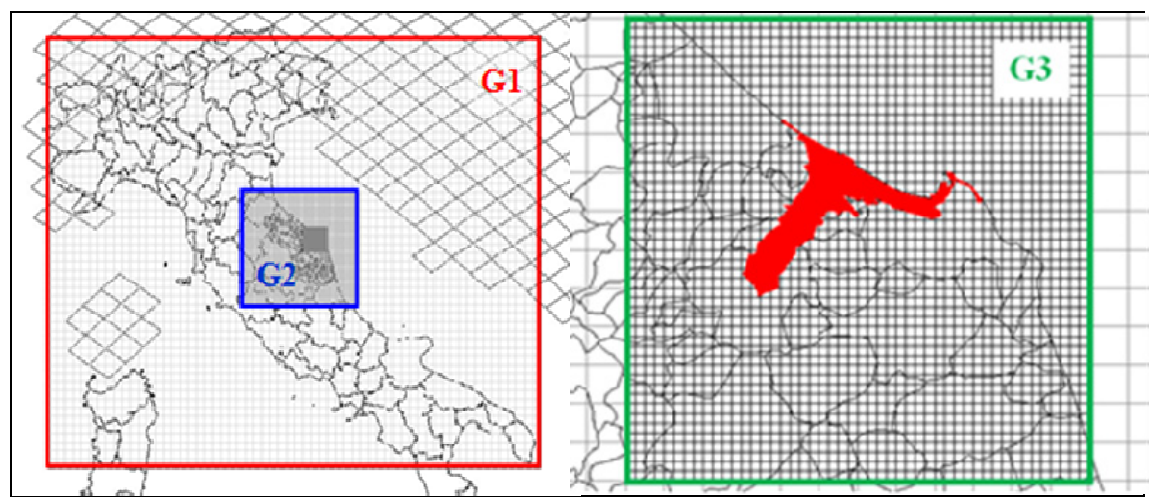

(a)

(b)

Figure 1: Master grid G1 and nested grid G2 (a); grid G3 (b) with area declared "Highly at Risk of Environmental Crisis" (AERCA) in red.

The second nested grid (G2) is $232 \times 219 \mathrm{Km}$ wide, well covers the Marche region, and is made of $58 \times 54$ cells of $4 \mathrm{~km}$ steps. The finest grid (G3) is $50 \times 50 \mathrm{~km}$ wide and is made of $50 \times 50$ cells of $1 \mathrm{~km}$ steps. It covers the AERCA restraint (Fig. 1(b)).

The air emission inventories here in use has been derived from the EMEP Centre on Emission Inventories and Projections [11] for the sources outside 
Italy, the Italian Emission Inventory 2005 [12] for all the provinces outside Marche Region, and the Emission Inventory [13] to the municipality level of Marche Region.

\subsection{Photochemical model}

CAMx (Comprehensive Air quality Model with eXtensions) is an Eulerian photochemical dispersion model that allows an integrated "one-atmosphere" assessment of gaseous and particulate air pollution (ozone, PM2.5, PM10, air toxics, mercury) over many scales ranging from sub-urban to continental.

CAMx simulates the emission, dispersion, chemical reaction, and removal of pollutants in the troposphere by solving the pollutant continuity equation for each chemical species on a system of nested three-dimensional grids [6]. The Eulerian continuity equation describes the time dependency of the average species concentration within each grid-cell volume as a sum of all of the physical and chemical processes operating on that volume.

\subsection{Source apportionment tool}

Ozone source apportionment (OSAT), in CAMx, tracks the contributions to each grid cell from emissions source groups, emissions source regions, initial conditions, and boundary conditions with reactive tracer species $\left(\mathrm{NO}_{\mathrm{X}}, \mathrm{VOC}\right.$, and $\mathrm{O}_{3}$ ). Tracers provide information on the relative importance of transport and chemistry [14]. To distinguish VOC and $\mathrm{NO}_{\mathrm{X}}$-limited regimes, the tool uses the Sillman's indicator. The tracers operate as spectators to the normal CAMx calculations so that the underlying CAMx predicted relationships between emission groups (sources) and ozone concentrations at specific locations (receptors) are not perturbed [6].

The emission data were roughly split into three different groups: Industrial (I: anthropogenic fixed point sources; from SNAP97 sector 1 to 6, and 9), Transport (T: road transport and other mobile sources; SNAP97 sectors 7 and 8) and Natural (N: agriculture, forest and other natural sources; SNAP97 sectors 10 and 11). The tool OSAT needs an input file called Source Map file that allows the user to indicate other subdomains of emission within the grid set before. A Source Map file is required for the master grid and optional for the nested ones. The Source Map was designed according to the borders of Italian Regions. Smaller regions were joined together.

\section{Operational evaluation results}

\subsection{Base case}

Our study was performed over four days, namely from August 25 to August 28 of 2006. The chemistry mechanisms activated was Carbon Bond IV [15] with 113 reactions and up to 76 species (up to 44 state gases, up to 22 state particulates and 10 radicals). 
The results of the first simulation are shown in Figure 2. The emission scenario is the base case, without any modification to the emission inventories. The boundary conditions, namely the primary and secondary pollutants released outside the grid G1, are evaluated from EMEP prescribed values [16].

The predicted concentrations are in agreement with measurements of the two monitoring stations placed in AERCA: "Chiaravalle/2" (Fig. 2) and "Falconara Scuola" (not reported). The differences are larger in the first two days of simulation, and then become smaller. The model needs at least two days of simulation to give acceptable results simply due to the self-tuning: ozone derived from initial and boundary concentrations have less weight percentage after the first two days. In Figure 3 the hourly amount of ozone formed is reported with respect to the condition of formation for all emission groups and all emission areas of August 28. It distinguishes between $\mathrm{NO}_{\mathrm{X}}$-limited $(\mathrm{O} 3 \mathrm{~N})$ and VOC-limited $(\mathrm{O} 3 \mathrm{~V})$. The initial and boundary tracers are ozone not

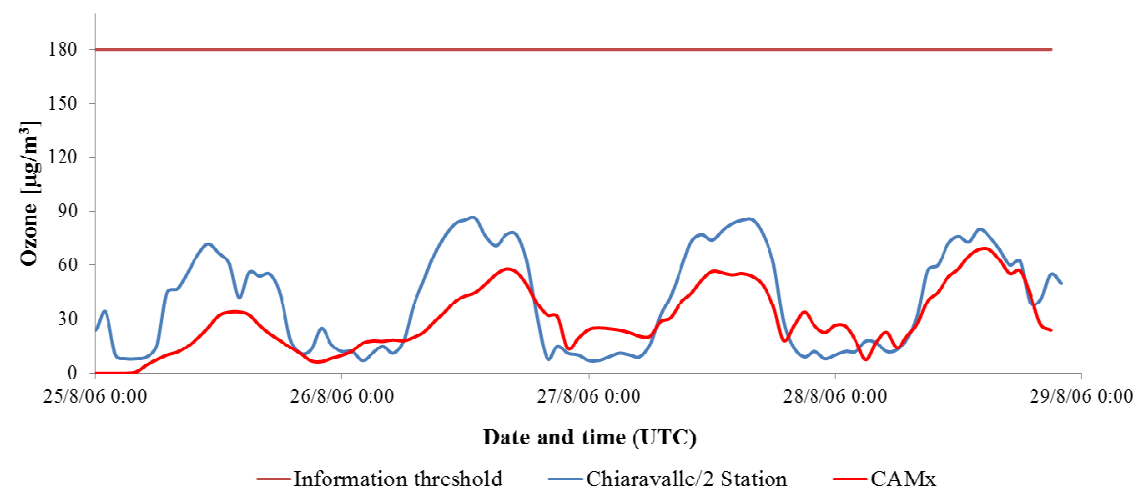

Figure 2: Results with EMEP boundary concentrations at "Chiaravalle/2" monitoring station.

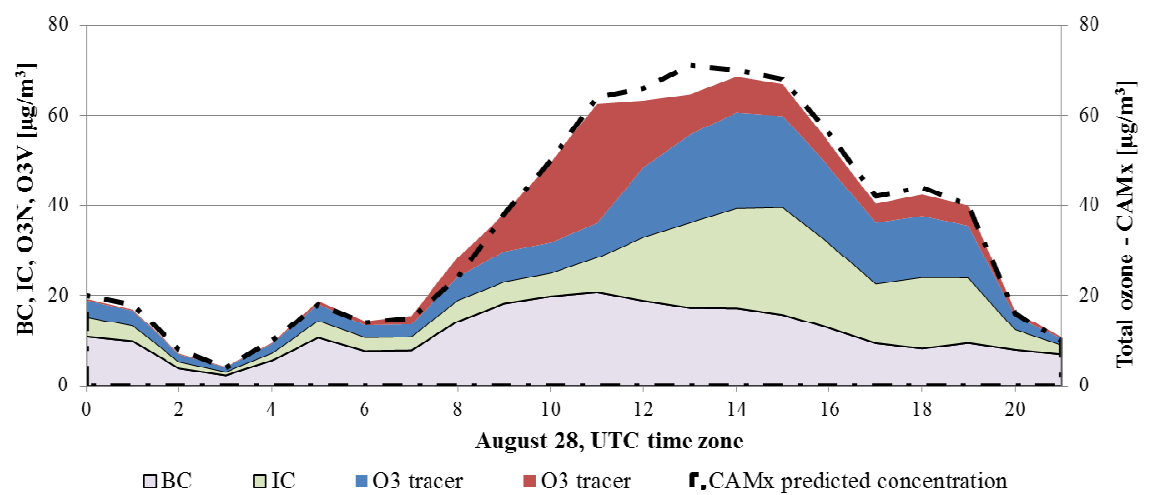

Figure 3: $\quad$ Source apportionment applied to "Falconara Scuola" monitoring station. 
chemically produced; this is released during the first hour of simulation or, continuously, in the lateral boundaries, respectively.

During the first part of the morning, at high concentration of $\mathrm{NO}_{\mathrm{X}}$, the reaction of the radical $\mathrm{HO}_{\mathrm{X}}$ is faster with $\mathrm{NO}_{\mathrm{X}}$ than with VOC and so the production of nitric acid, according to Formula (8), is high. The Sillman Indicator is below the transition point (VOC-limited situation) up to about 12:30 $\mathrm{PM}$. At this point, because of a low concentration of $\mathrm{NO}_{\mathrm{X}}$, the radical $\mathrm{HO}_{\mathrm{X}}$ reacts faster with VOC, the radical-radical reaction (9) becomes predominant and the Sillman indicator starts increasing ( $\mathrm{NO}_{\mathrm{X}}$-limited situation). The tracers in Figure 3 match this behavior. A detailed analysis carried out on the Area at High Risk of Environmental Crisis inside the finest grid (G3) has shown a more efficient ozone depletion, after sunset, over the main highway, an area where NO emissions are very high (removal of ozone via reaction (7) is favored).

\subsection{Ozone control strategies}

Information about ozone condition of formation could be very useful in tuning ozone control strategies so to reach acceptable air quality and to avoid ozone acute episodes. Generally, rural areas appear to be predominantly $\mathrm{NO}_{\mathrm{X}}$-limited: in this regime, an increase in $\mathrm{NO}_{\mathrm{X}}$ concentrations is always associated with increased ozone production. Conversely, in a VOC-limited situation, reducing the $\mathrm{NO}_{\mathrm{X}}$ emission will result in an increased ozone concentration since less $\mathrm{NO}_{2}$ will be available to reaction (8), then just a small amount will be transformed into $\mathrm{HNO}_{3}$. So, the rate of ozone formation is controlled by reactions (3) and (4) and increases with increasing VOC and decreases with increasing $\mathrm{NO}_{\mathrm{X}}$.

Several further simulations through speculative reductions of emission were carried out to investigate how alterations in emission scenarios can influence ozone behaviour in the area.

Figure 4 shows the ozone response in two hypothetical scenarios, the first one with $40 \%$ reduction of $\mathrm{NO}_{\mathrm{X}}$ and the second one with $40 \%$ reduction of VOC

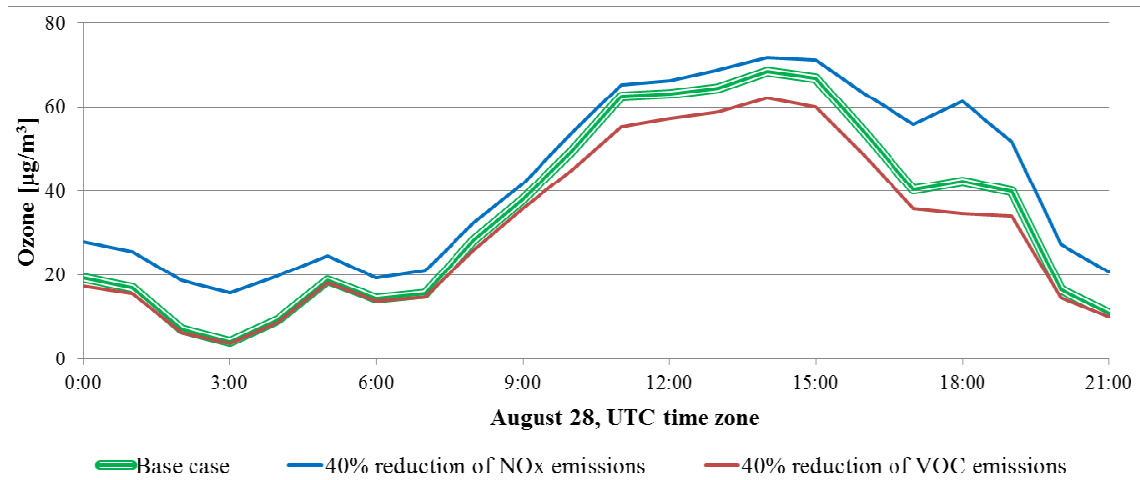

Figure 4: Ozone response to new emission scenarios, at "Falconara Scuola" site. 
emissions. As we can see, a $40 \%$ reduction of VOC emissions will result in lower ozone concentrations, while reduced $\mathrm{NO}_{\mathrm{X}}$ emissions, will trigger an increase of the ozone concentration.

In the simulation with $40 \%$ reduction of $\mathrm{NO}_{\mathrm{X}}$ emissions, the $\mathrm{NO}_{\mathrm{X}}$-limited situation happens before the one predicted by base case because of the different $\mathrm{VOC} / \mathrm{NO}_{\mathrm{X}}$ ratio given in input to the model. The higher this ratio is, the earlier the transition occurs.

The ozone behaviour should be matched with the $\mathrm{VOC} / \mathrm{NO}_{\mathrm{X}}$ ratio, including that measured at "Falconara Scuola" monitoring station. The monitored $\mathrm{VOC} / \mathrm{NO}_{\mathrm{X}}$ ratio is always above the transition point $\left(\mathrm{VOC} / \mathrm{NO}_{\mathrm{X}}>5.5\right)$, thus ozone formation is $\mathrm{NO}_{\mathrm{X}}$-limited. Conversely, CAMx model simulated a VOClimited situation in the first part of the morning followed, after midday, by a

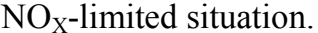

The differences between the predicted and measured $\mathrm{VOC} / \mathrm{NO}_{\mathrm{X}}$ ratio arise from hydrocarbons. Figure 5 shows the $\mathrm{NO}_{\mathrm{X}}$ monitored and predicted at "Falconara Scuola" station in the base case scenario: the values are similar. In fact, the uncertainty associated with emission of biogenic and anthropogenic hydrocarbons are high [7].

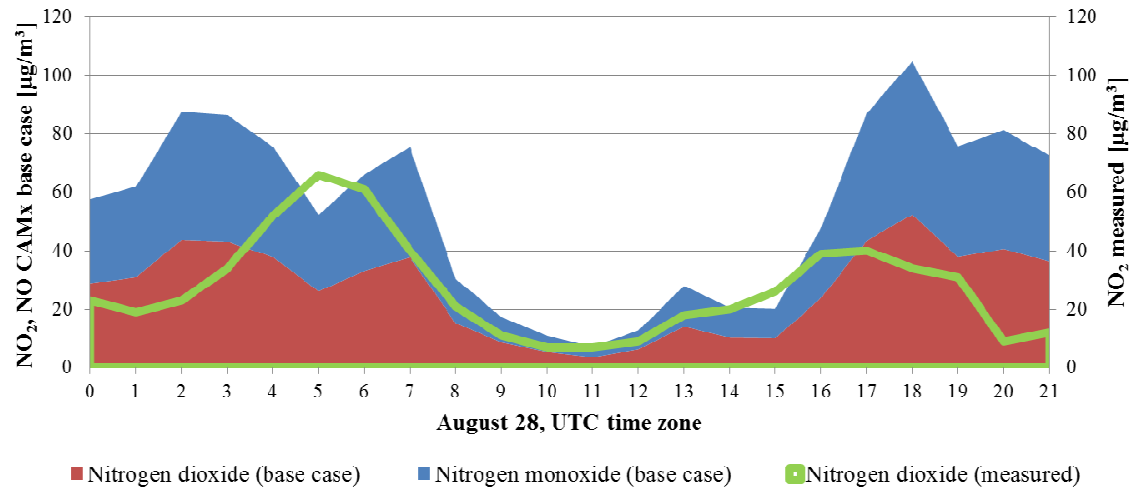

Figure 5: $\quad \mathrm{NO}$ and $\mathrm{NO}_{2}$ simulated by CAMx in base case scenario, and $\mathrm{NO}_{2}$ measured at "Falconara Scuola" monitoring station (green).

\subsection{Sensitivity to emission inventories}

Several scenarios were tested, using the data sets obtained from previous simulations, to better understand deviation between model results and measurements. In all of these, multiplicative factors to estimated hydrocarbons emissions of Marche Region were applied.

Figures 6-7 show the predicted hydrocarbons and ozone for the modified scenario in which VOC emissions were multiplied by five. This hypothesis is not as inconsistent as it might appear since VOC emission assessment is very hard in industrialised areas and a big petrochemical plant is located at short distance of 
monitoring station. As a matter of fact, VOC concentrations monitored by the same stations used for ozone assessment showed a massive presence of VOC incompatible with the officially recorded emissions.

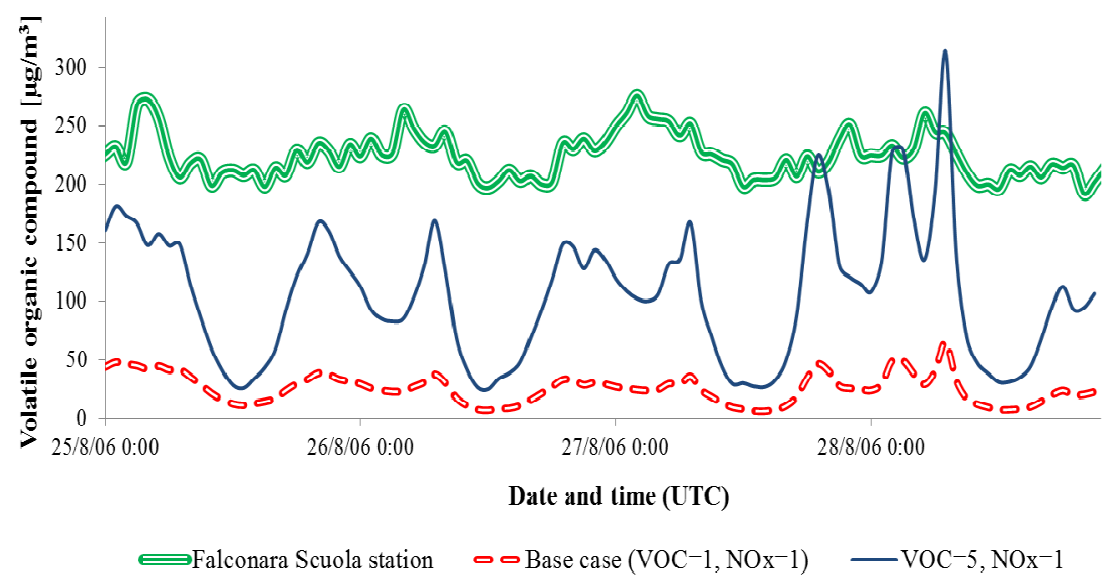

Figure 6: Monitored VOC and predicted for two emission scenarios at Falconara Scuola: base case and that with a factor of five.

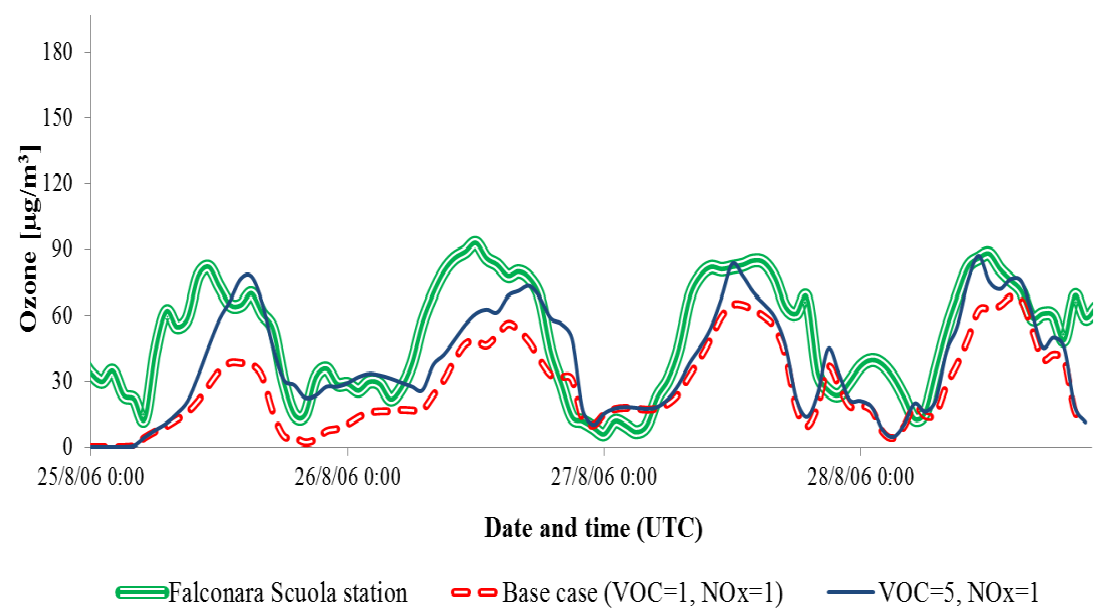

Figure 7: Results with new emission scenario at "Falconara Scuola" monitoring station. 


\section{Conclusions}

Results from base emission scenarios and modified emission scenarios show that the modelling system RAMS-EPS3-CAMx-OSAT well simulates the behaviour of ozone in many places of Marche Region.

The emission inventories are often the largest source of uncertainty in model predictions. Ozone fate and model sensitivity to ozone precursor depend critically on emission rates of anthropogenic $\mathrm{VOC}$ and $\mathrm{NO}_{\mathrm{X}}$, on their speciation, (especially of anthropogenic VOC), and on emission rates of biogenic VOC (biogenic hydrocarbons are usually highly reactive).

Control strategies can be very hard to establish since ozone concentrations are difficult to predict if there are not reliable data on emissions and concentrations of ozone precursors including, at least, a rough speciation.

Based on such evidence, policy makers must be aware that, under certain conditions, stopping industrial activities and/or private cars, with the aim of reducing ozone levels, may lead to exacerbation of phenomena and even to ozone episodes. In fact, reducing such human activities may lead to a further increase of $\mathrm{VOC} / \mathrm{NO}_{\mathrm{X}}$ ratio since most $\mathrm{VOC}$ are due to diffuse emissions while $\mathrm{NO}_{\mathrm{X}}$ are mostly stack and exhaust-pipe emissions.

\section{Acknowledgement}

This work has been supported by Fondazione Cariverona of Italy.

\section{References}

[1] Intergovernmental Panel on Climate Change (IPCC), Working Group II. Chapter 8: Human Health Section, "Climate Change 2007: Impacts, Adaptation and Vulnerability.

[2] Air Quality Directive, 2008/50/EC.

[3] Intergovernmental Panel on Climate Change (IPCC), Working Group I. Chapter 2: Changes in Atmospheric Constituents and in Radiative Forcing. Climate Change 2007: The Physical Science Basis.

[4] J. H. Seinfeld and N. Spyros. Atmospheric chemistry and physics: From Air Pollution to Climate Change. John Wiley \& Sons, 1998.

[5] S. Sillman. The use of $\mathrm{NOY}, \mathrm{H}_{2} \mathrm{O}_{2}$ and $\mathrm{HNO}_{3}$ as indicators for ozone- $\mathrm{NO}_{X^{-}}$ hydrocarbon sensitivity in urban locations, Journal of Geophysical Research, Vol. 100, pp. 14175-14188, 1995.

[6] Comprehensive Air Quality Model with Extensions, CAMx User's Guide, Version 5.30. Environ International Corporation, 2010.

[7] S. Sillman. The relation between ozone, $N O_{X}$ and hydrocarbons in urban and polluted rural environments, Atmospheric Environment, vol. 33, pp. 1821-1845, 1999.

[8] G. Latini, R. Cocci Grifoni, G. Passerini and S. Tascini, Modelling the interactions between sea breezes and valley breezes, $12^{\text {th }}$ Conference on Interactions of the Sea and Atmosphere, America Meteorological Society, 2003. 
[9] R. A. Pielke, W. R. Cotton, R. L. Walko, C. J. Tremback, W.A. Lyons, L. Grasso, M. E. Nicholls, M. D. Moran, D. A. Wesley, T. J. Lee, and J. H. Copeland. A comprehensive meteorological modeling system - RAMS. Meteorology and Atmospheric Physics, vol. 49, pp. 69-91, 1992.

[10] EPA-450/4-91-014. Procedures for the Preparation of Emission Inventories for Carbon Monoxide and Precursors of Ozone. Volume II: Emission Inventory Requirements for Photochemical Air Quality Simulation Models, 1991.

[11] Review of emission data reported under the LRTAP Convention and NEC Directive, Inventory Review 2013, CEIP - Centre on Emission Inventories and Projections.

[12] La disaggregazione a livello provinciale dell'inventario nazionale delle emissioni, Anni 1990-1995-2000-2005, Rapporti 92/2009, ISPRA.

[13] Piano di Risanamento e Mantenimento della Qualità dell'Aria Ambiente. Inventario delle emissioni in atmosfera. Allegato 1 alla DACR $\mathrm{n}$. 143/2010, Regione Marche

[14] G. Yarwood, R. E. Morris, M. A. Yocke, H. Hogo, T. Chico. Development of a Methodology for Source Apportionment of Ozone Concentration Estimates from a Photochemical Grid Model. Presented at the 89th AWMA Annual Meeting, 1996.

[15] M. W. Gery, G. Z. Whitten, J. P. Killus, M. C. Dodge. A Photochemical Kinetics Mechanism for Urban and Regional Scale Computer Modeling. Journal of Geophysical Research, vol. 94, pp. 925-956, 1989.

[16] Transboundary Acidification, Eutrophication and Ground Level Ozone in Europe. Chapter 8: Initial and Boundary Conditions Unified EMEP Model Description, EMEP Report 1/2003, Part 1. 